\title{
WHAT IS THE PRICE OF OUTDOOR ADVERTISING: A CASE STUDY OF THE CZECH REPUBLIC?
}

\author{
a JAROSLAV ZAHRÁDKA, 'VERONIKA MACHOVÁ, ' JIŘÍ \\ KUČERA \\ ${ }^{a}$ Institute of Technology and Business in České Budějovice, \\ School of Expertness and Valuation, Okružní 517/10, 37001 \\ České Budějovice, Czech Republic \\ ${ }^{b}$ Institute of Technology and Business in České Budějovice, \\ School of Expertness and Valuation, Okružní 517/10, 37001 \\ České Budéjovice, Czech Republic \\ ${ }^{c}$ University of Žilina, The Faculty of Operation and Economics \\ of Transport and Communications, Department of Economics, \\ Univerzitná 8215/1, 01026 Žilina, Slovakia \\ email: ${ }^{a}$ 27164@mail.vstecb.cz, ${ }^{b}$ machova@mail.vstecb.cz, \\ ${ }^{c}$ kuceraj@mail.vstecb.cz
}

Abstract: The aim of the paper is to analyze the price of outdoor advertising in various regions of the Czech Republic. The base source of data is the website plakatov.cz, from which the prices of outdoor advertisement in individual regions were obtained. The results show that the prices of outdoor advertisement in the individual regions are the same. The main difference is in how many outdoor advertisements are located in individual regions for the lowest and how many for the highest price. An overview was created, which shows what is the price of outdoor advertisement in each region, how many ads are located in each region and subsequently, the data is displayed using a map. The results show that the cheapest outdoor advertisement is located in the Hradec Králové region. The price of the outdoor advertisement in the Hradec Králové Region is CZK 5,204. On the contrary, the most expensive outdoor advertisement is in Prague. The price of outdoor advertising in Prague is CZK 16,567. Most outdoor advertisements are located in Prague. There are 174 outdoor advertisements in Prague. The lowest number of outdoor advertisements is in the Pardubice and Zlín regions. There are 18 outdoor advertisements in both regions. The difference between outdoor advertisements in the Pardubice and Zlín regions is in their price. While in the Zlín advertisements in the Pardubice and Zlin regions is in their price. While in the Zlin Region outdoor advertising costs CZK 6,466, in the Pardubice Region it costs CZK 12,333. The results are beneficial for people who are interested in outdoor advertising.
They are mostly beneficial for outdoor advertising producers to know their standing They are mostly beneficial for outdoor advertising
compared to their competition and other regions.

Keywords: advertising, outdoor advertising, outdoor advertising price, TV advertising price, trends in outdoor advertising

\section{Introduction}

The ubiquitous advertisements that we encounter on television, radio, the press and outside on the street have been affecting customers for decades, but the issue of outdoor advertising is not much addressed in research circles. It was this finding that strongly motivated us to address this issue. Advertising and other forms of commercial communications are entering a new world. Theorists are talking about a kind of revolution 4.0 full of digitization, automation, and robotics. It is supposed to bring a big change for consumers. There is speculation, for example, that we should receive products and services made, so to speak, tailor-made. Thus, the endless waste of resources, production for production and growth for growth will be reduced (Vysekalová and Mikeš, 2018).

Advertising has long appeared on various social networks. We can encounter it most often on, for example, Facebook, Instagram, or YouTube. For example, on YouTube we may encounter non-skippable and skippable advertisements. Skippable ads allow uninterested users to skip an ad after a few seconds. Skippable ads have seen great growth in recent years (Chakraborty, 2021). If we are watching an ad, the speed of expression of the actors in advertising plays a key role in understanding what the announcers are saying. When they are speaking too fast, we pay less attention to the true content of their speech. Rodero (2020) proved that people understood medium-speed advertising (180 words per minute) best.

In today's postmodern society, one of the key abilities is to attract recipients. Outdoor advertising also has this ability to attract recipients. Outdoor advertising, also known as advertising, away from home, is advertising that reaches consumers when they are outside of their place of residence. The most well-known types of outdoor advertising include billboards, posters, hanging signs. A big problem with these outdoor ads is their excessive luminosity. Excessive brightness of outdoor LED displays at night is widely used in urban areas, which poses potential safety risks for vehicle operation at night (He, 2021). Palmer (2021) states that a certain disadvantage of outdoor advertising is the fact that it can reinforce social inequalities in health. Vulnerable populations in disadvantaged areas may be more exposed to advertisements for fast food, gambling, and alcohol. This can encourage the consumption of fast food and alcohol. It can also entice a person to start gambling. The price of outdoor advertising in the Czech Republic depends on the type of outdoor advertising the customer requires. Another factor influencing the price of outdoor advertising can be considered the location (placement) of advertising. The aim of the paper is to find out what the price of outdoor advertising in the Czech Republic is. We will focus on the price of outdoor advertising in each region and then compare the prices of outdoor advertising in individual regions in the Czech Republic. We will find out in which region outdoor advertising is the most expensive, in which region it is the cheapest and how many advertisements are located in each region.

\section{Literature research}

Advertising is an integral part of our daily lives, because it is present everywhere (on the street, at work, at school, at home), accompanies us in every situation and affects us. Act No. 40/199 coll., on the regulation of advertising, states: "Advertising means an announcement, persuasion or other presentation disseminated mainly by communication media, aimed at promoting business activities, in particular promoting the consumption or sale of goods, construction, rental or sale of other real estate, sale or use of rights or obligations, promotion of services, promotion of a trademark, unless stated otherwise." There are several types of advertising. Recently, programmatic advertising has become very widespread. Programmatic advertising is a nascent and rapidly growing information technology phenomenon that responds to and influences consumers and their behavior. Calculating an ad budget is very difficult. To calculate an advertising budget, it's important what budget we have available. There is no general rule for determining the cost of advertising. There are usually four basic methods that can be used when creating a budget. These are: the residual budget method, the potential revenue share method, the competitive parity method and the goal-oriented method. There are different types of cost modeling for communication campaigns. They differ in the number of factors they take into account and the way they are used in practice. The experience we have with an implemented campaign is very important for compiling a budget (Vysekalová, Mikeš, 2018). Advertising can be encountered at every step. Outdoor advertising is one of the forms of communication between a company and the market.

Outdoor advertising includes various types of promotional banners, from roadside billboards to posters in vehicles and advertising in arenas, all of which focus on communicating to the public on a large scale. Digital billboards, as a new form of outdoor advertising, have gained popularity in recent years thanks to a revolutionary way of controlling when and where specific advertisements appear. However, this development also requires more complex optimization for strategic deployment. Huank (2020) proposed three optimization models that take into account different advertising needs: a dynamic audience model to maximize target audience coverage, a dynamic environment model to maximize target environment coverage, and a dynamic integrated model to jointly maximize target audience and environment. The results show that these proposed models are effective in providing an optimal solution for the digital configuration of the billboard, covering most of the target groups and the environment. It is very important for billboards to be placed in the right location. Zhang (2020) addressed the issue of influential billboard placement based on trajectory. Due to the set of billboards (U), the trajectory database (T) and the budget 
(L), he found a set of billboards within the budget. One of the main tasks is to identify and reduce the overlap of different billboards on the same trajectory. Belov (2020) has developed possible solutions to improve the adaptability of digital outdoor advertising. He created a mathematical model for placing smart ads and proposed an algorithm to find an effective schedule for displaying ads. An evaluation of the effectiveness of a set of ads placed in accordance with the proposed approach is provided as a sample check. The proposed model can be used to control a distributed outdoor advertising system using IoT technology. There is a problem quantifying the effectiveness of outdoor advertising. To solve this problem, it is proposed to use methods for evaluating the parameters of advertising and terminology, which are actively used in online advertising. However, pricing, placement and evaluation of the effectiveness of advertising messages on the Internet and on the street follow different rules. The main criterion for the effectiveness of this type of advertising on the Internet is the clickthrough rate. Wilson (2015) proposed a statistical model. This model is used to increase the efficiency of scheduling, to display ads, and also to determine where outdoor ads are placed. Using IoT technology, it is possible to collect information about microsections. To do this, we need to install a sensor at a selected location that can communicate with gadgets transmitted by people via $\mathrm{Wi}-\mathrm{Fi}$. The device works on the principle of scanning the surrounding space and collects MAC data of the device, which is not personal data. The system can also transmit aggregated data and study the dynamics of human flow. When creating a dynamic system, it will be necessary to solve problems with storing and processing very large amounts of data. A large number of factors affect outdoor advertising.

It is not clear what factors influence the recognition of outdoor advertising. Tsuji (2017) identified the effects of corporate colors and brand image on recognition. When ads use the corporate colors of the advertised companies, then it affects the recognition of outdoor advertising. To test this, he conducted two questionnaires. Consumers are more likely to recognize ads when the corporate colors of the advertised companies are used, and consumers are aware of what the corporate color is. The results show that consumers are more likely to recognize ads when the brand image is high for the advertised companies. Wilson (2015) conducted a field study of outdoor advertising along the city expressway, in which subjects follow a predetermined path. Upon their return, participants completed a short questionnaire that included road advertising rates. He also allowed participants to watch video scenes in the city, including seven outdoor ads that had been taken in advance, and asked if the subjects would recognize all seven outdoor ads. They then completed a second questionnaire, including whether or not the participants have a positive opinion towards outdoor advertising, and so on. In other words, Wilson (2015) conducted two questionnaires with the same participants: the first questionnaire contains questions about the brand image of the advertised companies, and the second questionnaire contains questions about whether or not consumers have a positive opinion on outdoor video advertising. The results show that corporate color is positively associated with the recognition of four corporate color ads: Apple, Western Digital, Y! On the other hand, corporate color has no significance in recognizing three corporate color ads: Panasonic, Capcom, and Sakai Construction. H1 consumers are therefore more likely to recognize ads when they use corporate colors supported by the advertised company, and when consumers know what the color is. In addition to normal factors, outdoor advertising is also affected by a large number of internal factors. Grigaliunaite (2019) conducted research aimed at establishing criteria for internal factors influencing the effectiveness of outdoor advertising. The criteria chosen were the font size of the title, the number of elements in the ad, and the dominant elements in the ad. The main research results show that when the surface size of visual and text outdoor advertising is the same, the text elements attract more visual attention than visual advertising. Ads that contain a large number of elements attract more visual attention than those that contain a small number of elements (Grigaliunaite, 2019). The prices of billboards have not changed much since the 1990s. Billboard space in a good location with nice visibility costs 5 to 6 thousand CZK. To these costs, the price for the graphic design and printing of the poster itself must be added. The price of the entire campaign is then easily calculated according to the number of spaces on which we have our advertisement put. The price of the billboard space is determined by several aspects. The most important thing is the attractiveness of the area - i.e. its location, proximity to a busy road, high throughput of vehicles and at the same time the abundance of pedestrians. The visibility of the area is also crucial. The billboard must be ideally rotated so that the driver has a perfect view of it. It should be perpendicular to the road or horizontally on the other side of the road. Logically, freestanding billboards attract more attention. There are 6 methods for determining the price of outdoor advertising (cost, demand, based on competition, according to the perceived value by the customer, detailed point method, document analysis)

\section{Data and methods}

\subsection{Data}

To achieve the aim of the paper, it is necessary to ask the following research questions:

1. What are the current trends in outdoor advertising?

2. To what extent does the price of outdoor advertising differ within the regions of the Czech Republic?

3. How different is the price between normal and outdoor advertising?

To answer the first research question, we will conduct a questionnaire survey. We will use the CAWI method. The CAWI method is a technique of gathering information in quantitative market surveys and public surveys in which the respondent is asked to complete the survey electronically. I will give the questionnaire to approximately 100 respondents. We will ask questions both in smaller cities and in larger ones, because, for example, there are more billboards in larger cities than in smaller ones. In smaller cities, a different type of outdoor advertising predominates. We will include both younger and older respondents in the questionnaire survey, because the older generation has a different view of outdoor advertising than the younger generation and vice versa. We process the data we obtain in Microsoft Excel. From the developed data, we will create a clear pie chart to show what the respondents consider to be the biggest trends in outdoor advertising and which outdoor advertising most often appears in cities. We decided on the pie chart because it is the most readable.

The data to determine the answers to the second research question will be obtained from the website plakatov.cz. We will evaluate the data from this website in Microsoft Excel software. From each region in the Czech Republic, we will determine the average price of outdoor advertising. We will create a map from the average prices we find in the application using Microsoft Excel. We will draw the map in PowerBi. For the map to display correctly in PowerBi, we need to put the data in the right places. In the location section, we put in regions. We will list the price of the billboards from each region in the Legend section. If we do everything correctly and enter the data in the right places, we will obtain a clear map of the outdoor advertising prices of each county. Below the map, we will add a legend noting the number of outdoor advertisements there are in each region, because the number varies greatly.

We obtain the data to answer the last question by finding the price of advertising on the most popular TV stations. From the data we get, we calculate an average price of TV advertising. For the average price of advertising, we express the highest price and the lowest price. We will utilize statistical functions and minimum and maximum to perform this task. We will also express the modus. With the modus, people will know what price is used most often. We will also calculate the average of the outdoor advertising prices. For the average price of outdoor advertising, we will also express the highest and lowest price. 
We will also express the modus here. Then we compare the average prices of TV and outdoor advertising.

\subsection{Methods}

A suitable method for determining the price of outdoor advertising would be to analyse documents (price lists). We have decided to compare how the price of outdoor advertising varies in different regions or districts. To find out the factors that affect the price of outdoor advertising we will need to know the composition of outdoor advertising. It will also be interesting to compare the price of outdoor advertising and television advertising. To evaluate the data, we will choose the method of comparison. For the first question we will choose the questionnaire survey method. For the last question we will choose the analysis of the price list of individual TV stations (Česká televize, Nova, Prima) and quantile analysis. Quantile analysis is an analysis that divides the set of observations and separates the number of highest and lowest values. Using this analysis we will find the lowest price of an advertisement, the highest price of an advertisement, the modus (the number that occurs most often in a set of data).

\section{Results}

What are the current trends in outdoor advertising? The questionnaire survey was completed by 100 respondents. The questionnaire survey was completed by respondents from larger and smaller cities. $52 \%$ of respondents were from larger cities, such as Prague, Pilsen, České Budějovice. $48 \%$ of respondents were from smaller villages.

As shown in Figure 1, 51\% of respondents were men and $49 \%$ were women.

Figure 1: Respondents’ gender

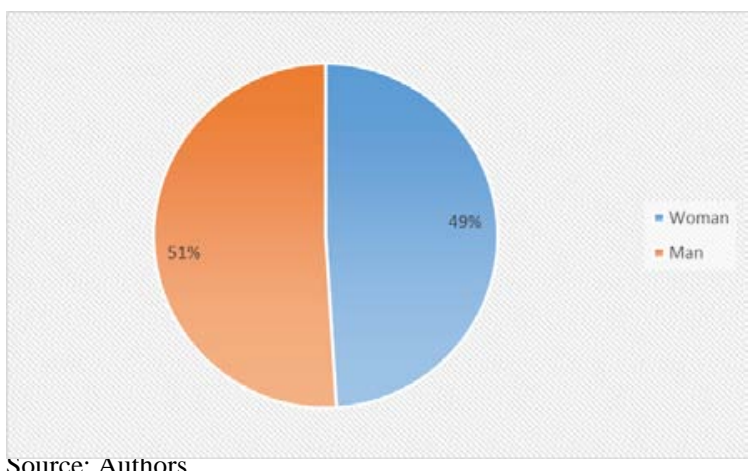

Figure 2 shows that the respondents were of different age categories: $48 \%$ of the respondents were younger than 20 years old, $19 \%$ of the respondents were $21-30$ years old, $16 \%$ of the respondents were $31-40$ years old, $10 \%$ of respondents were 41 50 years old and $7 \%$ of respondents were more than 50 years old.

Figure 2: Respondents' age category

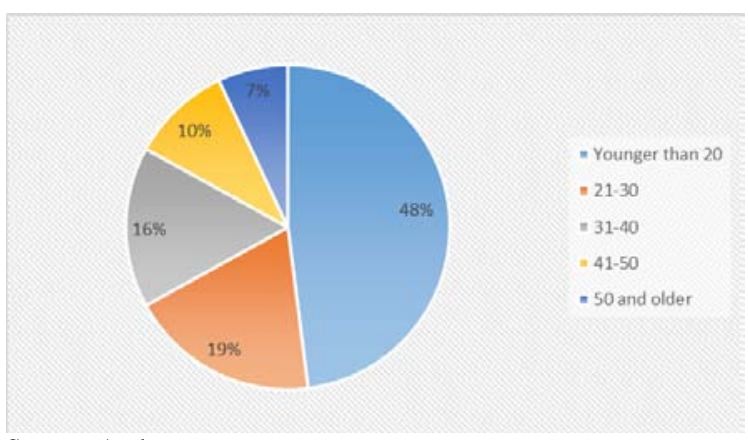

Source: Authors.
Figure 3 shows us the most seen types of outdoor advertising. Respondents most often see Posters. Posters are most often seen by $43 \%$ of respondents. Subsequently, they often see billboards. $36 \%$ of respondents see billboards the most. Signboards are the least seen. They are only seen by $21 \%$ of respondents.

Figure 3: The most seen types of outdoor advertising

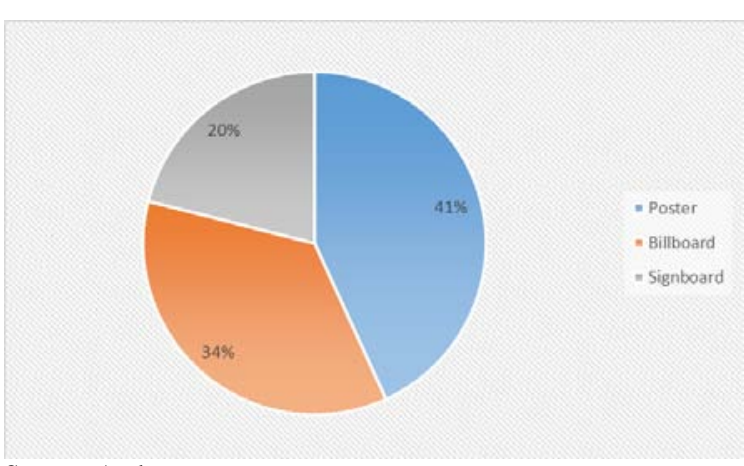

Source: Authors.

Figure 4 shows us the biggest trends in outdoor advertising. Respondents see the biggest trends in lighting (48\%). Subsequently, they see a big trend in movable advertising (32\%). They see another trend in better slogans (20\%).

Figure 4: Biggest trends in outdoor advertising

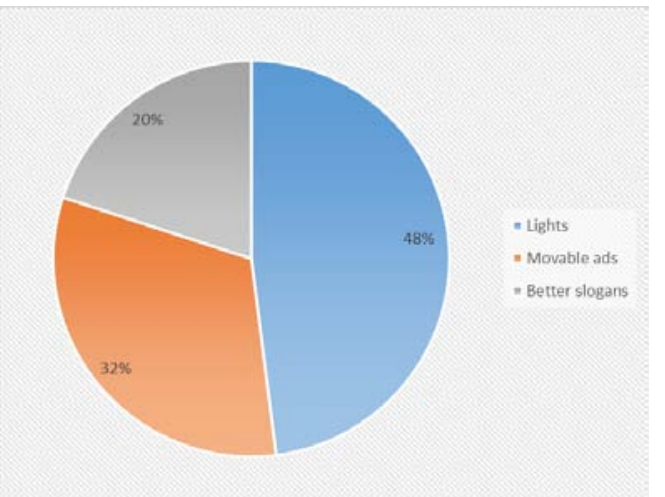

Source: Authors.

To what extent does the price of outdoor advertising differ within regions in the Czech Republic? The price of outdoor advertising does not differ much within the regions in the Czech Republic. We created a table (Table 1) and a map (Figure 5) to find out how much outdoor advertising costs, in which region and how many advertisements are located in each region.

Table 1: Price and number of outdoor advertisements in individual regions

\begin{tabular}{|c|c|r|}
\hline Region & $\begin{array}{c}\text { Average price } \\
\text { (in CZK) }\end{array}$ & $\begin{array}{c}\text { Number of outdoor } \\
\text { advertisements }\end{array}$ \\
\hline Jihočeský region & 7,744 & 42 \\
\hline Jihomoravský region & 9,234 & 79 \\
\hline Karlovarský region & 11,170 & 38 \\
\hline Vysočina region & 7,437 & 30 \\
\hline $\begin{array}{c}\text { Královehradecký } \\
\text { region }\end{array}$ & 5,204 & 50 \\
\hline Liberecký region & 3,643 & 94 \\
\hline $\begin{array}{c}\text { Moravskoslezský } \\
\text { region }\end{array}$ & 11,620 & 73 \\
\hline Olomoucký region & 11,613 & 18 \\
\hline Pardubický region & 12,333 & \\
\hline
\end{tabular}




\begin{tabular}{|c|c|r|}
\hline Plzeňský region & 11,545 & 34 \\
\hline Prague & 16,567 & 174 \\
\hline Středočeský region & 7,663 & 63 \\
\hline Ústecký region & 9,517 & 93 \\
\hline Zlínský region & 6,466 & 18 \\
\hline
\end{tabular}

Figure 5: Average price of outdoor advertising in individual regions

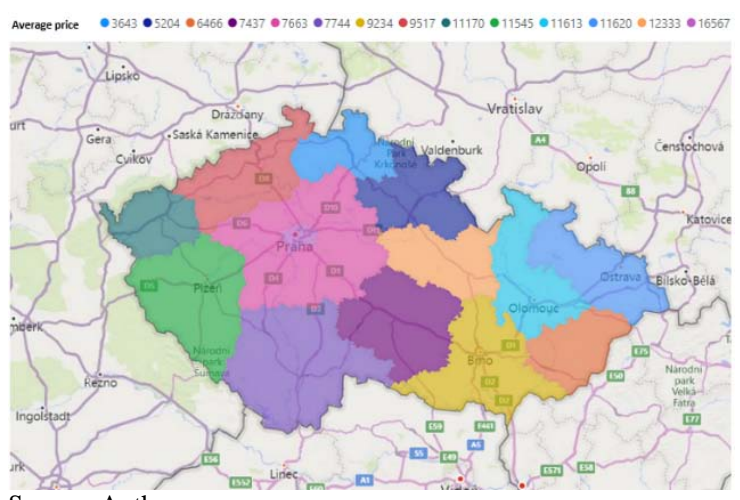

Source: Authors.

What factors influence the price of outdoor advertising compared to television advertising? We found out the price of television advertising of the three most popular channels: Nova, Prima and Česká televize.

Figure 6 shows the seasonal indices of Česká televize. Česká televize has the lowest advertising price in January and July. The price of advertising in January and July is CZK 21,600. On the contrary, the highest price of advertising is in December. In December, the price of advertising is CZK 58,050.

Figure 6: Seasonal indices of Česká televize

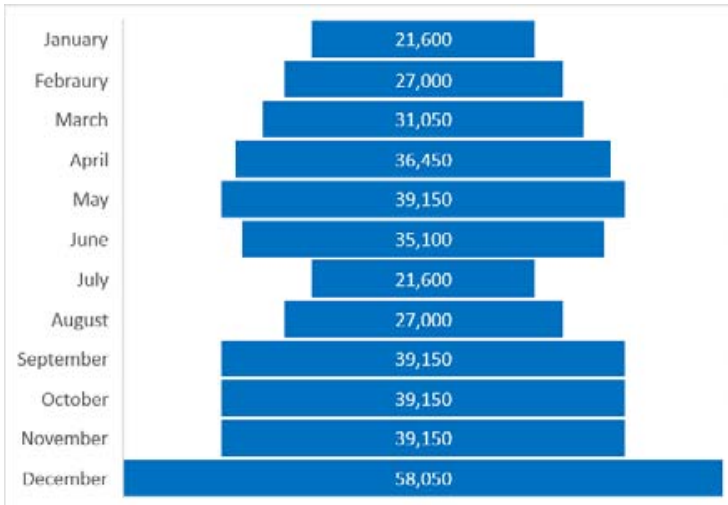

Source: Authors.

In Figure 7 we can see the timeframe indices of Česká televize.
Figure 7: Timeframe indices of Česká televize

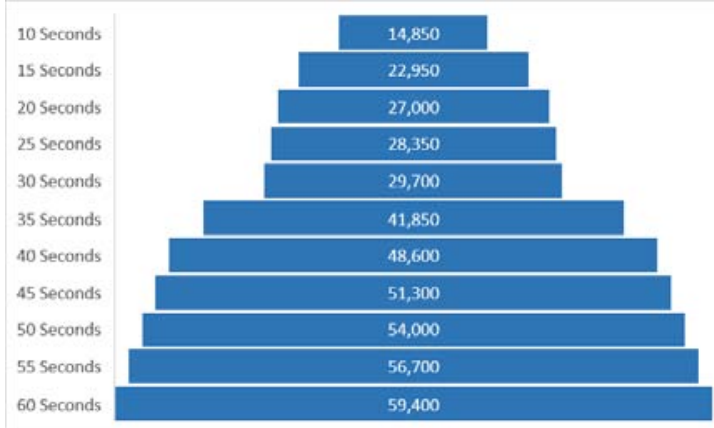

Source: Authors.

Figure 8 shows the price of advertising in each month on Prima. Prima has the lowest advertising price in January and July. The price of advertising in January and July is CZK 12,418. The highest price of advertising is in December. In December, the price of advertising is CZK 33,374.79.

Figure 8: Seasonal indices of Prima

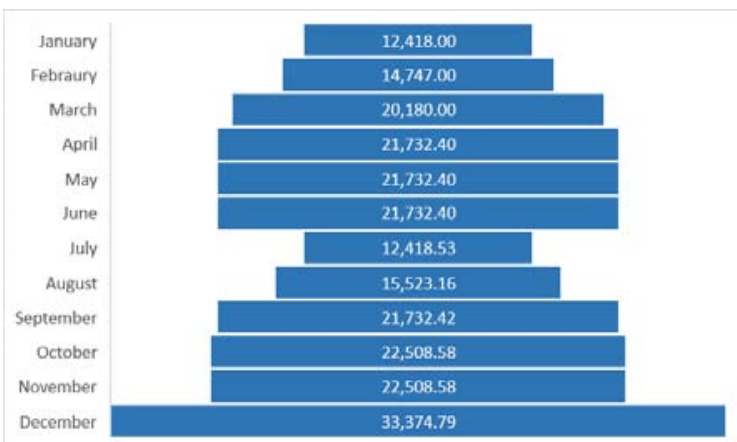

Source: Authors.

Figure 9 depicts the timeframe indices of Prima.

Figure 9: Timeframe indices of Prima

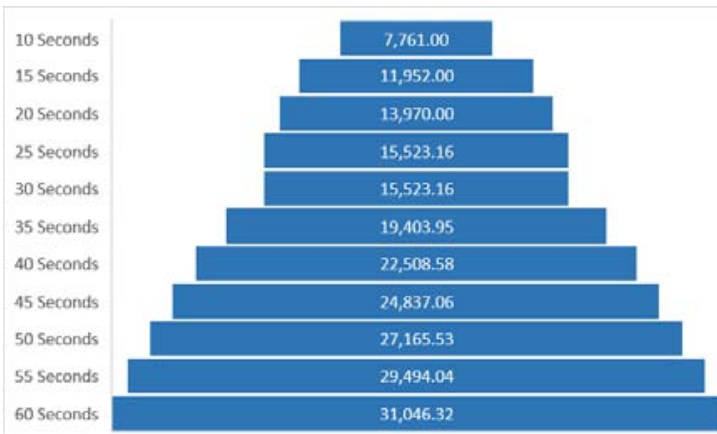

Source: Authors.

In Figure 10 we can see the price of advertising in individual periods on the TV channel Nova. The lowest price of advertising on Nova is in January. In January, the price of advertising is CZK 17,608.08. The highest price of advertising is in December. In December, the price of advertising is CZK 54,081.96. 
Figure 10: Seasonal indices of Nova

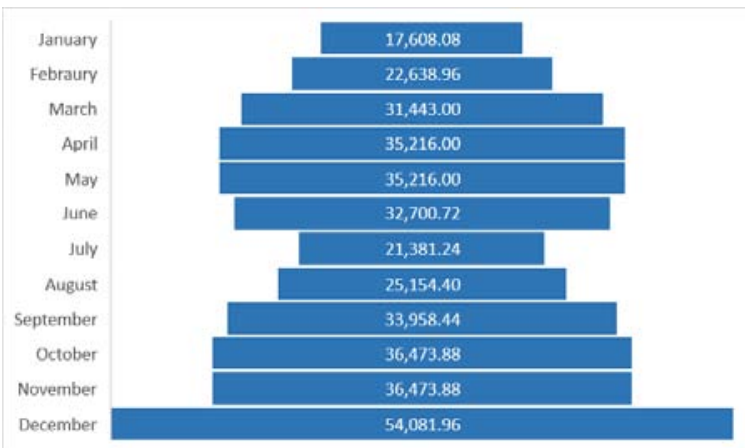

Source: Authors.

Figure 11 shows the timeframe indices of Nova.

Figure 11: Timeframe indices of Nova

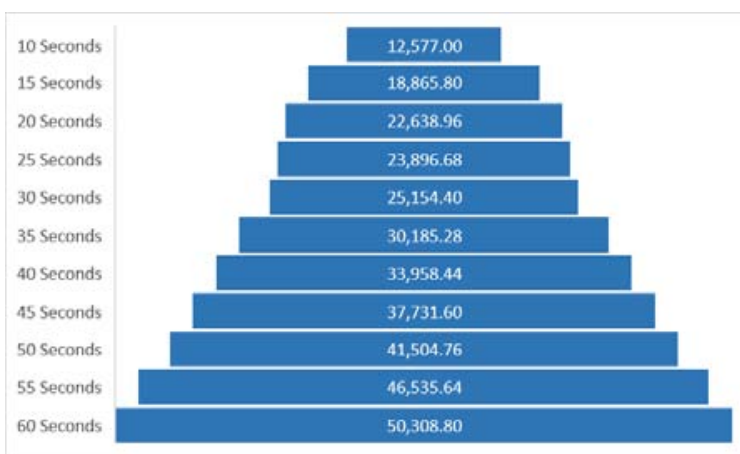

Source: Authors.

\section{Discussion}

Based on the obtained results, we are able to answer research questions which we determined earlier:

\section{1) "What are the current trends in outdoor advertising?"}

The questionnaire survey showed that the most seen type of outdoor advertising are posters, billboards and signboards. In Figure 3, we can see that posters are seen the most by $40 \%$ of respondents, billboards by $29 \%$ of respondents, and signboards by $18 \%$ of respondents. Figure 4 shows us current trends in outdoor advertising. Respondents noted the biggest trends are in lighting, movable advertising and better slogans. Lighting was the answer chosen by $42 \%$ of respondents, mobile advertising by $25 \%$ of respondents and better slogans by $15 \%$ of respondents.

2) "To what extent does the price of outdoor advertising differ between regions in the Czech Republic?"

What matters most is how big the city in which the outdoor advertising is located is. Larger cities have a larger number of outdoor advertisements, in smaller cities or villages, on the other hand, we do not encounter outdoor advertising very often. The prices of outdoor advertising are the same in each region, but it depends on how many ads are in the region for the lowest price and how many for the highest. The results show that the cheapest outdoor advertising is in the Liberec region, where the average price is 3,643 CZK, while the most expensive outdoor advertising is located in Prague, where it is also located most frequently, specifically here we can find 174 outdoor advertisements. The average price of outdoor advertising here is CZK 16,567. On the contrary, outdoor advertisements are least prevalent in the Zlín Region. There are 18 of them in the Zlín Region and the same number of outdoor advertisements can also be found in the Pardubice Region. The difference in outdoor advertising between the Zlín and Pardubice regions is mainly in regard to the price. In the Zlín Region, the average outdoor advertising costs CZK 6,466, while in the Pardubice Region the price is significantly more expensive. The average price for a similar advertisement here is CZK 12,333.

3) "How different is the price between normal and outdoor advertising?"

We analyzed the price lists of individual television stations (Nova, Prima, Česká televize) to find out the price of advertising of individual stations. In the analysis, we focused on sixtysecond television advertising and its development throughout the year. To find out the price of a television ad, we need to know the cost per rating point (CPP). When we find out the cost per rating point, we multiply the seasonal and timeframe indices for the individual period by this price, and after adding the seasonal and timeframe indices, we get the advertisement cost of individual stations.

The results show that the best price for television advertising is on the TV station Prima. The price of a 60-second television commercial on this station will cost CZK 459,792 per year. The highest price of advertising on Prima is in December, when its average price reaches CZK 33,375. On the contrary, the lowest price of advertising is in January (CZK 12,418). The modus of Prima (the most frequent price of advertising) is CZK 21,732. Nova has an affordable price for television advertising. The price of a TV commercial on Nova will cost CZK 725,703. The highest price of television advertising on Nova is also in December, when the price of television advertising is CZK 54,082 , while the lowest price is in January, in the amount of CZK 17,609. The modus of Nova is CZK 35,216. Česká televize has the least acceptable price for television advertising. The price of a television advertisement on Česká televize will cost CZK 849,150. As usual, the highest prices here are achieved by television commercials in December $(58,050 \mathrm{CZK})$ and the lowest in January $(21,600 \mathrm{CZK})$. The modus of the price of advertisements on Česká televize is CZK 39,150 ČT.

We analyzed the price lists of individual television stations (Nova, Prima, Česká televize) to find out the price of advertising of individual stations. In the analysis, we focused on sixtysecond television advertising and its development throughout the year. To find out the price of a television ad, we need to know the cost per rating point (CPP). When we find out the cost per rating point, we multiply the seasonal and timeframe indices for the individual period by this cost, and after adding the seasonal and timeframe indices, we get the advertisement price of individual stations.

In determining the price of a television advertisement, it plays a very important role in which month we want the advertisement to be broadcast and how long it should be. Compared to the prices of TV advertising, the prices of outdoor advertising per year are more advantageous.

The lowest price of outdoor advertising is in the Liberec Region, where we pay an average of CZK 43,176 per year. On the contrary, the highest price of outdoor advertising can be found in Prague, where the average annual price climbs to CZK 198,804

The results will be beneficial for people who are interested in outdoor advertising. They will be most beneficial for outdoor advertising producers to know their standing compared to their competition and other regions.

\section{Conclusion}

The aim of the paper was to find out how the price of outdoor advertising varies in the Czech Republic. From the plakatov.cz website, we found out the prices of outdoor advertising in individual regions in the Czech Republic. We analyzed the prices of outdoor advertising from individual regions using Microsoft Excel software and calculated the averages of outdoor advertising prices in individual regions. Therefore, the aim of the paper was achieved.

The price of outdoor advertising is the same in each region. It depends on how many outdoor advertisements a region offers at 
the lowest price and how many at the highest price. Another important role is played by the size of the city. In a smaller city, there is a smaller number of outdoor advertising, in a larger city there is a larger number of outdoor advertisements. The cheapest outdoor advertisement is located in the Liberec region. Here, the price of outdoor advertising is CZK 3,643. On the contrary, the highest price of outdoor advertising is in Prague. Here, the average price of outdoor advertising is CZK 16,567. The lowest number of outdoor advertisements is located in the Pardubice and Zlín regions. There are 18 outdoor advertisements in these regions. The difference between outdoor advertising in the Zlín and Pardubice regions is in the price. In the Zlín Region, an average of outdoor advertising costs CZK 6,466. In the Pardubice Region, outdoor advertising costs an average of CZK 12,333 . On the other hand, most outdoor advertising is located in Prague.

The results above lead to the following question -what are the biggest advantages and disadvantages of outdoor advertising? What kind of outdoor advertising is most common in the Czech Republic? How does the price of outdoor advertising in the Czech Republic differ from neighboring countries? Based on the data we have collected for this research, we are unable to answer these research questions. Therefore, it would be appropriate to carry out follow-up research to answer these and other emerging questions.

\section{Literature:}

1. Batool, S., Iqball, R.: Impact of green advertising on consumer purchase behavior. International Interdisciplinary Journal of Scholarly Research. 2016, 2(1). ISSN 2412-303X. 2. Belov, A., Ramov, Y.: Approach for increasing the adaptability of digital outdoor advertising. 2020 IEEE International IOT, Electronics and Mechatronics Conference (IEMTRONICS). 2020, 1-5 p.

3. Bylinskiy, Z., Nam, W. Kim, et al.: Learning visual importance for graphic designs and data visualizations. 30th Annual ACM Symposium on User Interface Software and Technology. 2017, 57-69 p.

4. ČT: Ceník pro televizní vysílání reklamy v České televizi [Price list for television broadcasting of advertising on Czech Television]. Česká televize. 2021 [online]. Prague, Česká televize 2021 [cit.2021-5-20]. From: https://www.ceskateleviz e.cz/vse-o-ct/reklama/televizni-reklama

5. Dulebement, M., Moses, R.: The highway beautification act: towards improving efficiency of the federal outdoor advertising control program. Transportation Research Part A: Policy and Practice. 2018, 110, 88-106 p. ISSN 0965-8564.

6. Grigaliunaite, V., Pileliene, L.: Arvydas Petras. The analysis of the influence of internal factors on outdoor advertising effectiveness. Research for Rural Development 2016: Annual 22nd International Scientific Conference Proceedings. 2016, 166-173 p.

7. He, Y., Xinshuo, Z., Li, Q., Rouyi, M., Young, C., Jingfeng, $\mathrm{X}$., Zhen, T.: Influence of coloured light projected from nighttime excessive luminance outdoor LED display screens on vehicle driving safety along urban roads. Building and Environment. 2021. 188. ISSN 0360-1323.

8. Huang, M., Zhixiang, F., Weibel, R., Zhang, T., Huang, H.: Dynamic optimization models for displaying outdoor advertisement at the right time and place. International Journal of Geographical Information Science. 2021, 35(6), 1179-1204 p. ISSN 1365-8816.

9. Hyman, M., Parvathi, J., Omar, W.: Advertising and the impact on stock price accuracy. Journal of Corporate Accounting \& Finance. 2021, 32(2), 90-101 p. ISSN 1044-8136. 10. Chakraborty, S., Sumanta, B., Saibal, R., Megha, S.: Advertisement revenue management: determining the optimal mix of skippable and non-skippable ads for online video sharing platforms. European Journal of Operational Research. 2021, 292(1), 213-229 p. ISSN 0377-2217.

11. Chytrý, M.: MojeBillboardy [MyBillboards]. Olomouc, Project promotion [online]. 2021 [cit.2021-21-5]. From: https://www.mojebillboardy.cz
12. Iqball, R., Batool, S.: Impact of billboard advertisement on customer buying behavior: a study on Islamia University of Bahawalpur (IUB). International Interdisciplinary Journal of Scholarly Research. 2016, 2(1), 9-15 p. ISSN 2412-303X.

13. Lesser, L., Zimmerman, F. Cohen, D.: Outdoor advertising, obesity, and soda consumption: a cross-sectional study. BMC Public Health. 2013, 13(1), 1-7 p. ISSN 1471-2458.

14. Maksimenko, S., Tkach, B., Lytvynchuk, L., Onufriieva, L.: Neuro-psycholinguistic study of political slogans in outdoor advertising. Psycholinguistics. 2019, 26(1), 246-264 p. ISSN 2309-1797.

15. Masařová, K.: Billboard - součást outdoorové reklamy, aneb, Žijeme $v$ džungli [Billboard - part of outdoor advertising, or, we live in the jungle] ? $1^{\text {st }}$ ed. Prague: Key Publishing, 2014. 154 p. ISBN 978-80-7418-206-8.

16. Palmer, G., Green, M., Boyland, E., Vasconcelos, Y. S. R., Savani, R., Singleton, R.: A deep learning approach to identify unhealthy advertisements in street view images. Scientific Reports. 2021, 11(1). ISSN 2045-2322.

17. Panhwar, M., Memon, K. A., Abro, A., Deng, Z. L., Khuhro, S. A., Memon, S..: Signboard detection and text recognition using artificial neural networks. 2019 IEEE 9th International Conference on Electronics Information and Emergency Communication (ICEIEC). 2019, 16-19 p.

18. Park, J., Lim, T., Yang, K. H., Ju, S., Jeong, S. M.: Dippingpress coating method for retaining transparency and imparting hydrophobicity regardless of plastic substrate type. Polymers. 2021, 13(3), 1-10 p. ISSN 2073-4360.

19. Permana, H., Safa, H., Fauzi, B.: Augmented reality in poster: Introduce sir Isaac Newton in the study of mechanics. 9th National Physics Seminar 2020. 2021.

20. Plakatov, 2018. Outdoor reklama - ceny [Outdoor advertising - prices]. Plakatov.cz [online], 2018. Prague, Bigmedia, spol. From: www.plakatov.cz

21. Prima: Příloha $\mathrm{k}$ smluvním obchodním podmínkám pro smlouvy o vysílání obchodních sdělení $\mathrm{v}$ TV programech zastupovaných FTV PRIMA, s.r.o. [Annex to the contractual terms and conditions for contracts on the broadcasting of commercial messages in TV programs represented by FTV PRIMA, s.r.o]. Prima. 2021 [online]. Prague, Prima FTV 2021 [cit.2021-5-20]. From: https://www.iprima.cz/sites/default/fi les/article/cenik_vop_tv_ftv_prima_2017.pdf

22. Rodero, E.: Do your ads talk too fast to your audio audience? How speech rates of audio commercials influence cognitive and physiological outcomes. Journal of Advertising Research. 2020, 60(3), 337-349 p. ISSN 0021-8499.

23. Tsuji, R.: What Factors Make Outdoor Advertising More Effective. Kansai University. 2017.

24. Vysekalová, J., Mikeš, J.: Reklama: jak dělat reklamu [Advertising: how to make an advertisement]. $4^{\text {th }}$ ed. Prague: Grada. 2018. ISBN 978-80-247-5865-7.

25. Zhang, P., Bao, Z., Li, Y., Zhang, Y., Peng, Z.: Towards an optimal outdoor advertising placement: when a budget constraint meets moving trajectories. ACM Transactions on Knowledge Discovery from Data. 2020, 15(5). ISSN 1556-4681.

\section{Primary Paper Section: A}

Secondary Paper Section: AH, AE 